УДК 504:613.96:364.122.5

(C) Н.П.Ковальчук, к.с.-г.н.

Луцький національний технічний університет

\title{
СКВЕРИ МІСТА ЛУЦЬКА ТА ЇХ ФУНКЦІОНАЛЬНЕ ЗНАЧЕННЯ
}

У статті детально проаналізовано та розкрито функиіональне значення скверів у міських екосистемах на прикладі м. Луиька. Визначено їх площу та розглянуто негативний вплив процесів урбанізації на міські екосистеми та місие в них людини. Виділено основні проблеми розвитку міста $і$ формування міських скверів в умовах урбанізації.

СКВЕР, МІСТО, ЕКОСИСТЕМА, ЗЕЛЕНІ НАСАДЖЕННЯ, ФІТОМЕЛІОРАЦІЯ, УРБАНІЗАЦІЯ

Постановка проблеми. Забезпечення нормальної екологічної ситуації у міських екосистемах сучасного урбанізованого середовища зводиться до екологічного балансу міста та навколишнього середовища, що стає можливим лише у випадку, коли загальний обсяг міського антропогенного навантаження на оточуюче середовище буде меншим або рівним обсягу хімічного, фізичного i біологічного впливів, котрі нейтралізуватимуться міськими біогеоценозами без власної шкоди.

У міських екосистемах формується своєрідне урбанізоване середовище, котре поєднує природну, соціальну та технічну системи, які комплексно формують простір людської діяльності.

Природна система урбанізованого середовища включає зелені зони на площах або вулицях, переважно в середині житлових забудов, які відіграють архітектурно-декоративну роль та використовуються для короткотривалого відпочинку - сквери.

Створюючи сквери у містах, розміщуючи більш рівномірно зелені насадження, можна отримати швидкий санітарно-гігієнічний та декоративний ефект. 
В умовах сучасності, стосунки живих організмів 3 навколишнім урбанізованим середовищем, виступають уже як соціальна проблема.

У зв'язку з цим ставиться завдання оптимізації міського середовища, котре постійно погіршується. Сьогодні, забруднення навколишнього середовища досягло особливо великих масштабів у містах, зокрема - у великих індустріальних центрах, поширюється та поглиблюється шкідливий вплив урбанізованого довкілля на людей. Дослідження впливу урбанізації на здоров'я людини $\epsilon$ досить складною і важливою проблемою. Чистота повітря, тобто його якість, відіграє вирішальну роль, оскільки здійснює безперервний вплив на людей. Гострота екологічної ситуації більшості міст світу спонукає містобудівничих шукати нові шляхи у плануванні та інфраструктурі міст.

На нашу думку, найбільш цінною і необхідною в складній ситуації урбанізації на глобальному рівні є фітомеліорація - один з напрямків прикладної екології, в межах якого досліджуються, прогнозуються, моделюються і створюються рослинні системи, діяльність яких спрямована на покращення геофізичних, геохімічних, санітарно-гігієнічних, біотичних, інтродукційних, просторових та естетичних характеристик екосистем.

У загальному виділяють такі фітомеліоративні аспекти покращення за допомогою зелених насаджень екологічної ситуації у великих і малих містах: зелені рослини вловлюють пил та деякі забруднюючі речовини, очищуючи навколишнє середовище; в результаті процесу фотосинтезу зелені насадження міста $\epsilon$ джерелом поповнення запасів кисню; фітонцидна функція рослин зменшує бактеріологічне забруднення середовища; зелені рослини іонізують повітря та виконують значну мікрокліматичну роль, тобто регулюють температуру повітря у спеку; рослини визначають основні закономірності радіаційного, теплового, водного, вітрового, геохімічного режиму території міста; озеленення знижує рівень шуму та вібрації в місті; наявність рослин підвищує зносостійкість будівель та споруд міста; рослини частково протидіють процесам ущільнення грунтів на міських територіях, значно "розвантажують" перший від поверхні землі водоносний горизонт, сприяючи зниженню його рівня і протидіють підтопленню міської території.

В умовах сьогодення, вельми актуальною $є$ проблема охорони навколишнього середовища і ландшафтів, зменшення негативного впливу процесів урбанізації, у якій особлива роль відводиться міським зеленим зонам, серед яких важливе місце займають сквери. На відміну від заміських рекреаційних пунктів, 
міських парків, сквери міст підлягають під категорію малодосліджених, хоча, в значній мірі, їм властиво зменшувати шкідливий урбогенний вплив та підвищувати комфортність життя людини в міській екосистемі.

Актуальність наших досліджень на сучасному етапі зумовлюється, як свідчать літературні дані, необхідністю подальшого вивчення особливостей розвитку та формування зелених насаджень у міських скверах в умовах зростаючої урбанізації.

Аналіз останніх досліджень і публікацій. На даний час проведено багато досліджень, щодо стану та розвитку міських зелених зон. Вказані проблеми розглянуто у працях як вітчизняних авторів Кучерявого В.П. “Зелена зона міста” [4], “Урбоекологія” [2], “Фітомеліорація" [4], “Природне середовище міста" [5], Курницька М.П. “Особливості життєдіяльності деревних порід в урбогенних умовах великих міст" [1]; Ковальчук Н.П. "Еколого-біологічні проблеми зелених насаджень м. Луцька”, так i зарубіжних: Вергунов А.П. “Архітектурно-ландшафтна організація великого міста"; Sukopp H., Wittig R. "Stadtokologie”, однак ціла низка питань залишається невирішеними.

Мета дослідження полягає у вивченні особливостей розвитку та формування зелених насаджень скверів м. Луцька. Сьогодні проведено багато досліджень щодо впливу процесів урбанізації на міські екосистеми та ролі зелених зон у містобудуванні. Вивчення та узагальнення набутого досвіду на сучасному етапі $є$ актуальним завданням з точки зору як екології, урбоекології, фітомеліорації, так і містобудування.

Результати дослідження. 3 кожним роком невпинно зростає вплив процесів урбанізації, розбудовуються міста та приміські зони, зростає антропогенний вплив на існуючі зелені зони, руйнуються природні ландшафти, котрі лише в межах природно-заповідного фонду зазнають найменших змін.

Місто Луцьк $є$ адміністративним центром Волинської області та згідно класифікації Є.М. Перцика належить до великих.

Для того, щоб зелені насадження ефективно виконували свої функції по насиченню повітря киснем, екзометаболітами, очищенню середовища від пилових i хімічних забрудників, по зниженню шуму, регулюванню клімату, рекреаційну функцію, потрібно дотримуватись певних містобудівничих правил та принципів ведення зеленого господарства.

Сучасне містобудівне формування зеленої зони - системи озеленених територій міста в поєднанні із заміськими (лісами, 
лісопарками, лугопарками, гідропарком) регламентується державними будівельними нормами (ДБН 360-92**, ДБН Б.1-397) Постановою Кабінету Міністрів України № 733 від 16.05.07 p. "Про затвердження порядку поділу лісів на категорії...”, природоохоронним законодавством, і в існуючій та передбаченій генпланом системі озеленення міста (зеленій зоні) повинні бути присутні усі три групи озеленених територій, що визначаються за функціональною ознакою, зокрема сквери, які належать до групи озеленених територій загального користування.

У сучасному Луцьку налічується 30 скверів (табл. 1), які займають 19,32 гектара, що становить 8,2 \% від площі загального користування, котра складає 235, 6223га та всього лише 0,46 \% від загальної площі міста (42000000 м²). Якщо прийняти кількісний склад населення Луцька на рівні 2014 року, що становив 217225 чоловік, то звідси слідує, що на одну людину припадає $10,85 \mathrm{M}^{2}$ зелених насаджень загального користування м. Луцька. За міжнародними нормами на одного міського жителя даний показник має бути не менше, ніж $20 \mathrm{~m}^{2}$ на одну людину.

На нашу думку, такий показник $\epsilon$ дуже низьким та неприпустимим, оскільки, в середньому з розрахунку на одного жителя від пересувних джерел забруднення у м. Луцьку припадає по 47кг. Негативні тенденції, які спостерігаються останнім часом у зеленому будівництві Луцька, зокрема, скорочення площ насаджень, обсягів посадок, збіднення асортименту посадкового матеріалу, високий рівень уражень різними захворюваннями, ущільнення грунтів, різноманітні механічні пошкодження рослин, високий рівень техногенного впливу, низький рівень агротехнічних методів і прийомів призводять до того, що існуючі насадження не в змозі виконувати покладені на них фітомеліоративні функції. Від периферії до центру міста прослідковується тенденція зменшення видової кількості рослин та спрощується структура культурфітоценозів. В такому ж порядку умови місцезростань ксерофілізуються і в насадженнях зростає частка ксеромезофітів, оскільки рослини в центрі міста зростають фактично в екстремальних екологічних умовах. 


\section{Сільськогосподарські машини. Випуск 43}

Таблиця 1- Сквери міста Луцька

\begin{tabular}{|c|c|c|}
\hline №п/П & Назва та місце розташування & Площа (га) \\
\hline 1 & Проспект Перемоги 10 & 0,2652 \\
\hline 2 & $\begin{array}{c}\text { Вулиця Лесі Українки (навколо } \\
\text { пам’ятника Бойку C.I.) }\end{array}$ & 0,1151 \\
\hline 3 & $\begin{array}{c}\text { Перетин вулиці Лесі Українки та } \\
\text { вулиці Олени Левчанівської }\end{array}$ & 0,0941 \\
\hline 4 & Вулиця Ковельська (Братський міст) & 0,1404 \\
\hline 5 & Сквер Героїв Майдану & 3,52 \\
\hline 6 & Вулиця Львівська & 0,0627 \\
\hline 7 & Проспект Відродження & 0,4917 \\
\hline 8 & Вулиця Даргомижського & 0,0682 \\
\hline 9 & Проспект Волі & 2,10 \\
\hline 10 & Київський майдан (біля ОДА) & 0,53 \\
\hline 11 & $\begin{array}{c}\text { Вулиця Шопена (поруч бібліотеки } \\
\text { імені Олени Пчілки) }\end{array}$ & 0,3256 \\
\hline 12 & Проспект Молоді (біля клубу „3000”) & 0,55 \\
\hline 13 & Проспект Волі 49 а (поруч „Сіті парк”) & 3,00 \\
\hline 14 & Проспект Волі (біля гімназії №4) & 0,6 \\
\hline 15 & Проспект Волі 31-33 & 0,22 \\
\hline 16 & $\begin{array}{c}\text { Проспект Соборності (поруч храм Bcix } \\
\text { Святих землі Волинської) } \\
\end{array}$ & 1,1 \\
\hline 17 & Проспект Волі 12 & 0,50 \\
\hline 18 & Вулиця Кравчука (біля ТЦ „Слон”) & 0,36 \\
\hline 19 & $\begin{array}{c}\text { Вулиця Лесі Українки - вулиця } \\
\text { Кривий Вал }\end{array}$ & 0,02 \\
\hline 20 & Вулиця Винниченка 4 & 0,065 \\
\hline 21 & Вулиця Рівненська & 2,5 \\
\hline 22 & Пам’ятник Св. Миколаю & 0,1773 \\
\hline 23 & Вулиця Д. Галицького & 0,0930 \\
\hline 24 & Готель „Україна” - вулиця Винниченка & 0,1082 \\
\hline 25 & Вулиця Ранкова - вулиця Цукрова & 0,8191 \\
\hline 26 & Проспект Молоді 11-13 & 0,4911 \\
\hline 27 & $\begin{array}{c}\text { Вулиця Корольова (поруч пам’ятник } \\
\text { Т.Г. Шевченку) } \\
\end{array}$ & 0,2503 \\
\hline 28 & Проспект Волі 52-54 & 0,2666 \\
\hline 29 & Проспект Волі 39 а & 0,0410 \\
\hline 30 & Проспект Відродження 32 & 0,4517 \\
\hline 31 & Загальна площа скверів & 19,3253 \\
\hline
\end{tabular}


Висновки. У місті Луцьку налічується 30 скверів, які займають 19,32 гектара, що становить 8,2 \% від площі загального користування та всього лише 0,46 \% від загальної площі міста, що $\epsilon$, на нашу думку, досить низьким показником.

Негативні тенденції спостерігаються у зеленому будівництві Луцька, зокрема, скорочення площ насаджень, обсягів посадок, збіднення асортименту посадкового матеріалу, високий рівень уражень різними захворюваннями, ущільнення грунтів, різноманітні механічні пошкодження рослин, високий рівень техногенного впливу, низький рівень агротехнічних методів і прийомів призводять до того, що існуючі насадження не в змозі виконувати покладені на них фітомеліоративні функції.

Отже, головним завданням, на сьогодні, є збереження існуючих зелених зон загального користування, зокрема скверів м. Луцька, поповнення їх асортименту новими витривалими до міського середовища видами $з$ подальшим розширенням їх меж та необхідністю термінового створення нових скверів, як важливих буферних елементів комфортності життя міського населення.

\section{Література}

1. Курницька М.П. Особливості життєдіяльності деревних порід в урбогенних умовах великих міст (на прикладі м. Львів): Автореф. дис. канд. с.-Г. наук: 06.03.01 / Укр.ДЛТУ. - Львів, 2001. - 19 с.

2. Кучерявий В.П. Урбоекологія. - Львів: Світ, 2001. - 439 с.

3. Кучерявий В.П. Фітомеліорація. - Львів: Світ, 2003. - 539 с.

4. Кучерявый В.А. Зеленая зона города. - К.: Наукова думка, 1981. - $247 \mathrm{c.}$

5. Кучерявый В.А. Природная среда города. - Львов: Вища школа, 1984.- 144 с. 